\title{
Factor Analysis of Employee Engagement of Generation Y in Padma Hotel Bandung
}

\author{
Ria Fransisca Ifa Evendy ${ }^{\# 1}$, Ade Irma Susanty ${ }^{\# 2}$ \\ ${ }^{\#}$ Magister Management, Telkom University \\ Bandung, Indonesia \\ ${ }^{1}$ riafransiscaiedstudent.telkomuniversity.ac.id \\ 2adeirma@telkomuniversity.ac.id
}

\begin{abstract}
Today, there has been a shift in the labor force, where $Y$ generation dominates the company's human resources. Human resource is a company's vital asset because it's role and function cannot be replaced by other resources so it needs special treatment to maintain loyalty to the company. One way to get employees to have high loyalty is employee engagement. Employee engagement is considered more important than employee satisfaction, because with employee engagement, employees aren't only doing the maximum effort exceed expectations but also affect the employees' decision to stay. This study aims to analyze the factors of Generation $Y$ employee engagement. There are seven factors in this research, namely vigor factor, dedication, absorption according to Schaufeli et al and leadership, achievement, camaraderie, and equity according to Sirota Consulting LLC. The study population is Generation Y employees at Padma Hotel Bandung that will be analyzed using confirmatory factor analysis. The result shows that the level of Gen Y employee engagement at Padma Hotel Bandung is included in high category that is equal to $76.756 \%$. By using factor analysis, there are thirteen determinants of employee engagement, namely equity, personal resources, leadership, dedication, achievement, absorption, kinship, team work, uneasy feeling, unyielding, vigor, and task alignment. From the thirteen factors, it can be seen that the equity factor is the most dominant factor.
\end{abstract}

Keywords - Employee Engagement, Gen Y

\section{INTRODUCTION}

MICE industry development in Indonesia began to increase rapidly, this can be seen from the increase in MICE activities as well as the number of convention and hotel buildings equipped with meeting room facilities to support MICE activities. The rapid activity of MICE in big cities and bestselling convention buildings encourages hotels to take part in the procurement of MICE services. The hotel, which initially only moved in the field of leisure turned into MICE organizer in low-season. Most hotels currently offer MICE packages with the main components of the room where MICE is held and rooms to accommodate MICE participants. Increased MICE activities encourage the improvement of other accommodation support facilities within the hotel.

The high potential of business in the field of hospitality will trigger competition between hotels. With high levels of competition, hotel entrepreneurs compete to stay in business. Hotels are advised to develop excellent service and efficient and have complete facilities and adequate as a strategy to attract more guests. Not infrequently hotel competition is often colored by tariff war. From the various strategies that the strategy provides excellent service and facilities that memadailah selected by Padma Hotel Bandung as a way to attract more guests.

TABEL I

FIFTH STAR BANDUNG HOTEL RATING BASED ON TRIPADVISOR

\begin{tabular}{|c|l|c|}
\hline No & \multicolumn{1}{|c|}{ Hotel } & Rank \\
\hline 1. & Padma Hotel Bandung & 1 \\
\hline 2. & The Trans Luxury Hotel Bandung & 2 \\
\hline 3. & New Naripan Hotel & 3 \\
\hline 4. & Sheraton Bandung Hotel \& Towers & 4 \\
\hline 5. & Hilton Bandung & 5 \\
\hline
\end{tabular}

Table 1 shows the position of Padma Hotel Bandung as the most recommended five star hotels based on Tripadvisor. In addition, table 1 also shows the competitor Padma Hotel Bandung. Ratings based on this Tripadvisor may change at any time following reviews provided by visitors. Therefore assessment can change daily. It is not easy for Padma Hotel Bandung to be able to occupy the position of the top 5. A remarkable achievement has been achieved by Padma Hotel Bandung with the 1st rank in a row for 3 years starting from 2014.

To deal with the tight competition, there are some things that must be owned by the 
organization that includes physical resources, financial resources, marketability, and human resources ([5]). Furthermore, [5] states that of the four factors, the human resource factor becomes the key factor to create competitive advantage of the organization or company. Manager of SDM Padma Hotel Bandung, Mr. Ikhsan confirmed that employees are an asset for the company even more because Padma is a company engaged in services.

HR is a vital asset because the company's roles and functions cannot be replaced by other resources so it needs special treatment to maintain its loyalty to the company. In line with this, many efforts must be made by the company to create a climate or a positive work environment so that employees have a good engagement with the company. One way to get employees to have high loyalty is employee engagement. Employee loyalty levels are a problem for some companies including Padma Hotel Bandung.

Employee turnover rate Padma Hotel Bandung averages $38 \%$ over the period 2014 to 2016 . According [9], if the turnover value above $15 \%$ indicates that the turnover of employees included in the high category. A similar opinion is put forward by Branham (2009: 12), if the annual turnover in an organization exceeds $10 \%$ then turnover within the organization can be categorized as high. Turnover can have a positive and negative impact on the organization. If the organization loses $20 \%$ of employees who have high performance then it has a negative impact, but if the organization loses $20 \%$ of employees who have low performance then it has a positive impact. Therefore, organizations must maintain a growth rate of employee turnover. For Padma Hotel Bandung, the turnover has a negative impact, especially in providing services to guests.

This high level of employee turnover is dominated by $\mathrm{Y}$ generation employees. Unlike previous generations, $\mathrm{Y}$ generation has a distinctive feature characterized by this generation growing with full employment opportunities for women, respecting ethnic and cultural diversity, and increasing understanding of technology Better (Hawkins et al., 2007 in [2]). In addition to having privileges, Gen Y also has a negative side, Eisner (in [11]) mentions a problem for the organization regarding the existence of Gen $\mathrm{Y}$ in terms of attachment. The issues that arise relate to Gen Y that require flexibility in work, the quality of the work environment is adequate, and expect them to work on organizations that implement work-life balance.

The negative side of Gen $\mathrm{Y}$ makes Padma Hotel's dilemma largely because Padma has an employee composition dominated by Gen Y especially on the operational part. This is indicated by the number of employees of Gen Y as many as 118 people from 146 people or $80.82 \%$ of employees overall. By dominating Gen Y, management hopes to increase the productivity of the company. That's because management assesses $\mathrm{Y}$ genes more creative, communicative, and innovative in providing services to guests. But it also poses a challenge for companies to see Gen Y that has a stereotype that works only as a stepping stone or just to seek experience and move to another place (job-hopping) for career development to be achieved, so often perceived as unfaithful or committed low .

The high turnover rate as well as Gen $\mathrm{Y}$ is dominated by the company. One of the impacts is the cost to be spent on the recruitment process, the costs for training new employees, the time to be spent on recruiting, and training new employees, as well as other impacts. This disturbs the effectiveness of hotel operational work considering the level of achievement that is expected Padma is a leader hotel five star Bandung. To be able to achieve these dreams Padma must excel in the competition between hotels by highlighting the quality of service whose role is held by human resources.

\section{REVIEW OF LITERATURE}

\section{A. Generation $Y$}

Gen Y or better known by various other names such as Millennial Generation, Echo Boomers, New Boomers, Global Generations is a generation born in the period 1977-2002 with an age range of 22-39 years. Another opinion expressed by [23] states that the $\mathrm{Y}$ generation are those born between 1977-1994. Generation Y was born amid rapidly advancing information technology, so this generation has a very different character from previous generation better known as Generation X. 
Erickson ([6]) states that Y generation has a characteristic that they are a multicultural generation, have high volunteerism, confidence, and also intelligent in technology. Generally speaking, these generations are individuals who want to be rewarded for their effort, in the hope that they will get constant praise [4]. In contrast to previous generations, $\mathrm{Y}$ generation has the privilege, Generation $\mathrm{Y}$ grew up with full employment opportunities for women, respect for ethnic and cultural diversity, and improved understanding of better technology (Hawkins et al., 2007 in [2]) . Not only has the privilege, Gen Y also has a negative side. Generation $\mathrm{Y}$ who has worked shows an attitude that always contrary to office regulations, the generation of lazy, demanding many things, and not good at thanking. However, this generation may be praised for being energetic, courageous, and most of them capable of being strong leaders. The $\mathrm{Y}$ generations do everything in balance, when the hours are over, then it's over what they do, and they really need time other than to work. Like vacation with family and friends, because in work too they prefer to work together. Therefore Generation Y hopes they can work on organizations that implement worklife balance [2].

\section{B. Employee Engagement}

According to McLeod (2009:89) "employee engagement is an emotional attachment to work and organization, motivated and able to provide their best ability to help succeed from a set of tangible benefits to organizations and individuals." While Kreitner \& Kinicki (2014:29) states that: "Employee attachment is defined as the involvement, satisfaction and enthusiasm of one to work". The position of employee engagement is vital to achieve success and provide competitive advantage to the company. McLeod (2009:92) says that: "The engaged organizations have authentic power and value, with clear evidence of trust and fairness based on mutual respect, both of which have promises and commitments between employers and employees that are understood and fulfilled." Therefore it is necessary to establish employee engagement. A good engagement can be formed from reciprocal relationships between organizations and employees.
1) Vigor: Vigor is an aspect characterized by high levels of strength and mental resilience in work, a desire to strive earnestly in the work, persistent in the face of adversity. Wilmar [22] states that: "Vigor is assessed by the following six items that refer to high levels of energy and resilience, the willingness to invest effort, not being easily fatigued, and persistence in the face of difficulties.

- At my work, I feel bursting with energy

- At my job, I feel strong and vigorous

- When I get up in the morning, I feel like going to work

- I can continue working for very long periods at a time

- At my job, I am very resilient, mentally

- At my work I always persevere, even when things do not go well

Those who score high on vigor usually have much energy, zest and stamina when working, whereas those who score low on vigor have less energy, zest and stamina as far as their work is concerned."

2) Dedication: The aspect of dedication is characterized by a feeling that is full of meaning, enthusiasm, inspiration, pride and challenging in the work. People who have high dedication scores strongly identify their work because it makes it a valuable, inspiring and challenging experience. In addition, they usually feel enthusiastic and proud of their work. Wilmar Schaufeli \& Arnold Bakker [22] states that: "Dedication is assessed by five items that refer to deriving a sense of significance from one's work, feeling enthusiastic and proud about one's job, and feeling inspired and challenged by it.

- I find the work that I do full of meaning and purpose

- I am enthusiastic about my job

- My job inspires me

- I am proud on the work that I do

- To me, my job is challenging "

3) Absorption: The absorption aspect is characterized by deep concentration and interest, drowning in the work, time passes so fast and the individual is difficult to escape from work so that and forget everything around. People who have high scores on absorption are usually delighted to be consumed by work, feeling lost in work and having difficulty separating themselves from work. As a result, anything around him is forgotten and time passes quickly. Wilmar Schaufeli \& Arnold Bakker [22] states that:

"Absorption is measured by six items that refer to being totally and happily immersed in one's work and having difficulties detaching oneself from it so that time passes quickly and one forgets everything else that is around.

- Time flies when I'm working

- When I am working, I forget everything else around me

- I feel happy when I am working intensely 
- I am immersed in my work

- I get carried away when I'm working

- It is difficult to detach myself from my job "

Sirota Consulting LLC is a research and consultancy firm in New York that aims to measure employee engagement levels to improve the performance of their client organizations. According to [14], the company Sirota Consulting has conducted research as many as 237 organizations around the world from various industries by looking at two aspects of what employees want to the organization / company and its work (achievement, camaraderie, and equity), and aspects of leadership that The leader in the company do.

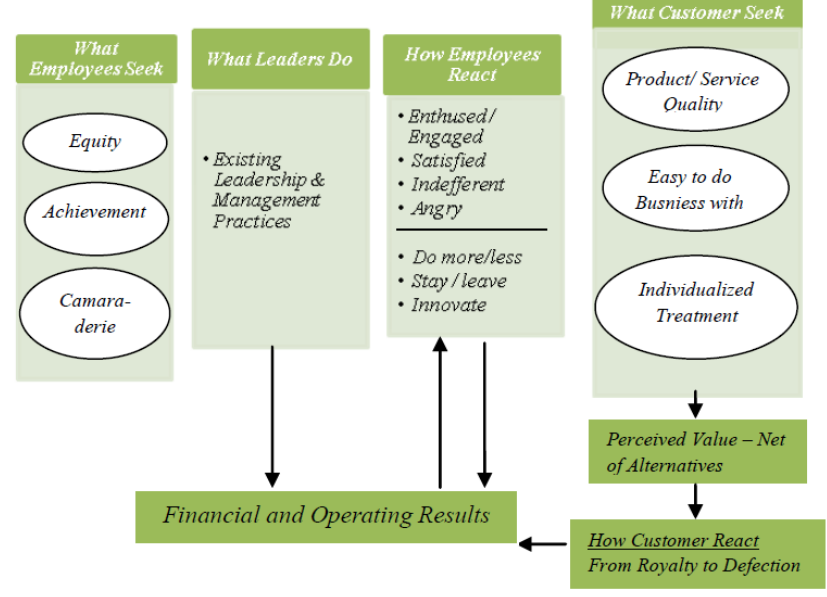

Fig 1 Sirota Survey Intelligence's Framework

Based on figure 1 above, here is a description of these factors:

1) Leadership: Leadership is the process of influencing the activities of individuals and groups in an effort to achieve goals in certain situations (Blancard and Hersey in Sutrisno 2009: 214). According to Sirota Consulting LLC website www.sirota.com, one of the factors employee engagement that can improve performance is leadership. Attitudes or behavior of a manager to his subordinates in an organization / company can affect the high level of attachment of each employee. Armstrong \& Taylor [1] states that: "The elements found to be fundamental for engagement were strong leadership ...". From the above statements can be concluded that the existence and influence of a leader / leader directly affect the performance of both individuals and groups in achieving common goals. Employees who have good relationships and thoughts that aligned with leaders will tend to be more motivated to improve their performance is also directly proportional to the level of employee engagement of the company. As the Gallup Organization notes based on interviews with 12 million employees at 7,000 companies over the past 40 years, relationships with superiors determine how long an employee is at work. One of the basic roles of the leadership team is to ensure that managers and supervisors -people who are fundamental points in business strategy are perfectly aligned with business strategy, capable of aligning and motivating others [32]. Robbins \& Judge (2008: 6) states that leadership is a process that includes the provision of people's organizational motivation, selection of the most effective channels of communication, and conflict resolution. According to Development Dimensions International (cited by Markos and Sridevi, 2010: 91), to create a high engagement, a manager must do several things, including:

- Aligning with business strategy

- Promote and encourage teamwork and collaboration

- Assist employees to grow and develop

- Provide support and recognition accordingly

2) Achievement (Recognition of work achievement): Employees will be enthusiastic and motivated to work if they get good recognition from the company. Such recognition includes recognition of work achievement and recognition of himself / herself. According to Sirota in [15], achievement is a feeling of pride that comes from doing important work and doing well, earning recognition, and appreciation for achievements both individually and in the work team. In measuring achievement, Sirota Survey Intellegence in [25] used several indicators to see if the employee received proper recognition. These indicators are job challenges, opportunities for growth, the ability to get things done, feelings about the importance of work, rewards for performance and a sense of pride in the company. According to Schiemann [23], the acknowledgment of work achievement can also encourage employees, such as employees motivated by team recognition while others seek and strive for individual recognition. There are six main key achievement factors according to Sirota \& Louis (2005: 15), among others:

- The challenge of his own work

- Acquire new skills.

- Able to show the results of his own work.

- Employment of employees is important.

- Recognition received from its performance, such as financial (compensation and bonus) and non-financial (thanks from leaders or customers).

- Working in an organization / company where employees are proud of it

3) Camaraderie (Kinship): One of the other factors employee engagement is camaraderie that a good relationship between employees both with superiors, subordinates, and with colleagues. According to Sirota LLC camaraderie is: "Having warm, interesting, and cooperative relations with others; Achieving a sense of community, belonging, and collegiality "(http://www.sirota.com, accessed on January 17, 2017). The level of stability and productivity of a company is built on relationships. Everyone in the organization depends 
on each other's knowledge and expertise [7]. Relationships between employees either in the form of formal or informal relationships need to be fostered well to achieve corporate goals. Such relationships will create a harmonious working environment. Bangun (2012: 325-326) says that affiliation is reflected in a person's desire to create, maintain, and connect the atmosphere of spiritual and mutual feelings among fellow human beings in the organization. People who have a high need for affiliation usually love affection and tend to avoid disappointment because of being rejected by a social group. The ultimate goal of gaining friendship with colleagues within the organization, preferring cooperative situations versus competition, and loving relationships that involve a high degree of understanding. According to Sirota in Kourdi (2009:161) the most significant aspects of the camaraderie factor, as follows:

- Relationships with colleagues

- Cooperation among employees in the business unit work.

- Teamwork across departments at specific company locations.

- Cooperation between work teams throughout the organization

4) Equity: According to Sirota \& Louis (2005: 10-11), one of the factors employee engagement in an organization / company is fair treatment in accordance with its work. Employee fairness perceptions according to Fahrudin (2004: 158) refers to employees to the fairness and balance between the inputs they provide with the organizational results they receive, as well as the employee's perception of the fairness of the processes used to distribute The organizational results. The theory of justice (equity theory) emphasizes the human ego who always crave justice in reward and punishment for each behavior is relatively similar. Justice is the driving force that motivates one's work morale. In this case, the boss is required to be fair to every employee. According to Kaye \& Sharon (2003: 39), talented employees will leave the leadership that he deems unfair because unfair treatment shows a lack of respect in the minds of many employees. Assessment and recognition of subordinate behavior should be done objectively, not on the basis of like or dislike. This will give the perception that the boss in the compensation or punishment done with objective and fair (Sutrisno, 2009: 142). In measuring fairness or equity, this study uses indicators according to the Sirota Survey Intellegence in [15]. According to Sirota, justice here is a feeling that what an employee receives has the right and equal to the work they have done. Here are three indicators of justice according to Sirota:

- Working conditions (physiological aspects)

- This aspect is more emphasis on the working environment conditions experienced by employees. Work environment conditions that provide comfort and security will make employees feel basic needs in work has been met so that there is an indication that the work environment obtained by employees is fair.

- Compensation (economic aspect)

- This aspect emphasizes more on compensation for what employees have done. The application of justice in this compensation can be seen from whether the employee feels that the salary and benefits he gets is in accordance with the work he is doing. If the salary and allowances given are appropriate then the application of fairness in economic aspects is good.

- Fair feelings (psychological aspect)

- This aspect emphasizes the employee's sense of justice. If the employee has felt treated fairly and respectfully in the workplace, then the application of justice in the psychological aspect is good. Fair and honorable is meant to be treated consistently and treated equally with other colleagues.

Kourdi [14] explains that: "Equity is the most important factor in shaping employee engagement. When equity is rated low, overall enthusiasm can be twothirds lower. "Which means if the achievement level and camaraderie is high while the level of equity received by employee.

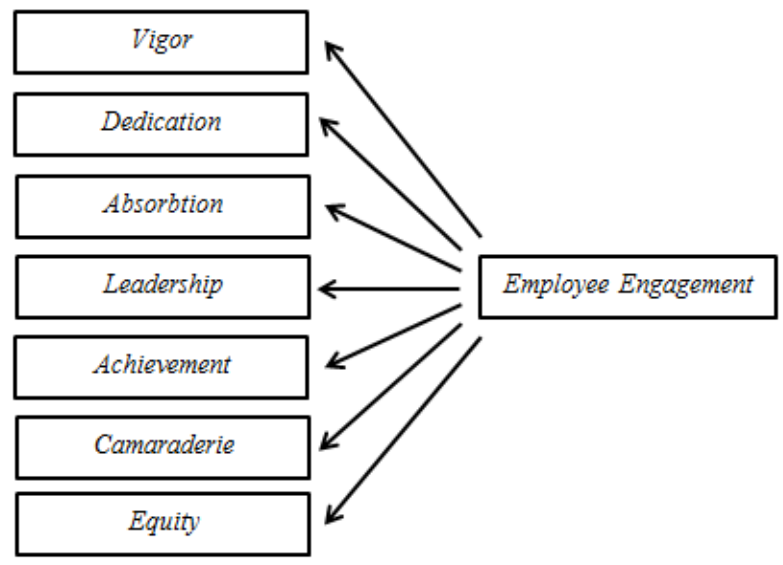

Fig 2 Framework

\section{RESEARCH HYPOTHESIS}

Based on this framework, the hypothesis in this study is that there is a dominant factor of employee engagement.

\section{Methodology}

The research method used in this research is descriptive method on each factor and tested the validity and reliability for each item questionnaire. Then the data were analyzed by using confirmatory factor analysis with SPSS 20.0. The population in this research is 98 employees of $\mathrm{Y}$ generation Padma Hotel Bandung. The sampling technique used is the census technique, which is one type of probability sampling technique. 


\section{DISCUSSION}

\section{A. Descriptive Statistics Analysis}

Descriptive analysis provides an overview of the data obtained in this study. Through descriptive analysis, it can be seen the frequency of each answer questionnaire distributed to respondents as below:

- The vigor factor index is included in very high category, ie with an average index of $89.12 \%$.

- The dedication factor index is included in very high category, ie with an average index of $84.24 \%$.

- The absorbtion factor index is included in the high category, ie with an average index of $76.80 \%$.

- Leadership factor index included in the high category, ie with the average index of $73.79 \%$.

- Achievement factor index included in high category, that is with average index equal to $76.41 \%$.

- The Camaraderie factor index is included in the high category, ie with an average index of $77.86 \%$.

- Equity index included in the high category, ie with the average index of $78.43 \%$.

\section{B. Factor Analysis}

1) KMO and Bartlett Test: The total factors used in this study are 7 factors that are contained in 48 questionnaire questions. All factors studied were input into SPSS for analysis by factor analysis. KMO and Barlett's Test were used to determine whether or not feasible factor analysis was performed in this study. Figure 1 shows the KMO Measure of Sampling Adequacy (MSA) of 0.746. A MSA greater than 0.5 indicates that factor analysis is feasible.

TABLE II

KMO AND BARTLETT'S TEST

\begin{tabular}{|c|r|}
\hline Kaiser-Meyer-Olkin Measure of Sampling Adequacy. & .746 \\
Bartlett's Test of Sphericity & Approx. Chi-Square \\
df & $3.435 \mathrm{E} 3$ \\
Sig. & .000 \\
\hline
\end{tabular}

2) Anti-image Matrices: The next process is to determine the feasible data in the process in the factor analysis, by looking at the value of MSA (Measure of Sampling Adequecy) on the anti-image correlation matrix. MSA values less than 0.5 indicate that these variables are not feasible for use in factor analysis to be eliminated. The value of MSA seen in the anti-image correlation matrix, is the number of numbers that make up the diagonal (which is marked "a"). The anti-image correlation matrix can be seen in the attachment section. The overall anti-image results of the variables can be further analyzed using factor analysis.

3) Communalities: Data communalities, which are used to obtain extraction values. The value of this extraction is essentially the amount of variance that can be explained by the factor to be formed. The smaller the value of extraction shows the weaker the relationship of these variables with the factors formed, and vice versa. The full results can be seen in the attachment section. From table communalities shows that the lowest extraction value is 0.625 is the statement "I do not pay attention to other things when doing my job" (VAR00013). This means that $62.5 \%$ of the variant of the VAR00013 statement can be explained by the new factor to be formed. While the highest extraction value is 0.909 is the statement "I get the benefits (allowances) in accordance with my position" (VAR00053). This means that the $90.9 \%$ variant of the VAR00053 statement can be explained by the factors formed. Likewise that applies to other statements.

4) Total Variance Explained: In this study, the authors determine the number of factors with eigenvalue with eigenvalue criteria $\geq 1$ [8]. The order of eigenvalue is always sequential from the largest value to the smallest value. To know the number of factors formed from the extraction can be seen in the attachment. Total Variance Explained results show that of the 48 indicators included in the factor analysis, there are 13 factors formed because of the factors numbered 1 to 13 have eigenvalue $\geq 1$. While indicator number 14 has eigenvalue of 0.911. It can be concluded that this research has 13 indicators that most optimal.

5) Factor Interpretation: After forming a factor through the Total Variance Explained process, the next step is to interpret the factors formed by looking at the component matrix table showing the distribution of 13 factors formed on 48 overall indicators. The value listed in the component matrix table is the loading factor, which shows the magnitude of the correlation between a variable with the factors that are formed. The results of the factors can not be interpreted because the variables that exist only collect on one or several factors are not comprehensive. For that factor rotation needs to be done.

6) Rotation Matrix: Rotation of this factor aims to get a clear view of the value of loading for each variable against the factors that exist. This interpretation is based on the largest loading value of each variable on the factors that exist, so a variable will enter in the factor that has the largest loading value, after a large comparison of the correlation of each line. The results of the factor rotation process can be seen in the attachment sheet 4. Based on the Rotation Matrix table formed 13 , namely: 


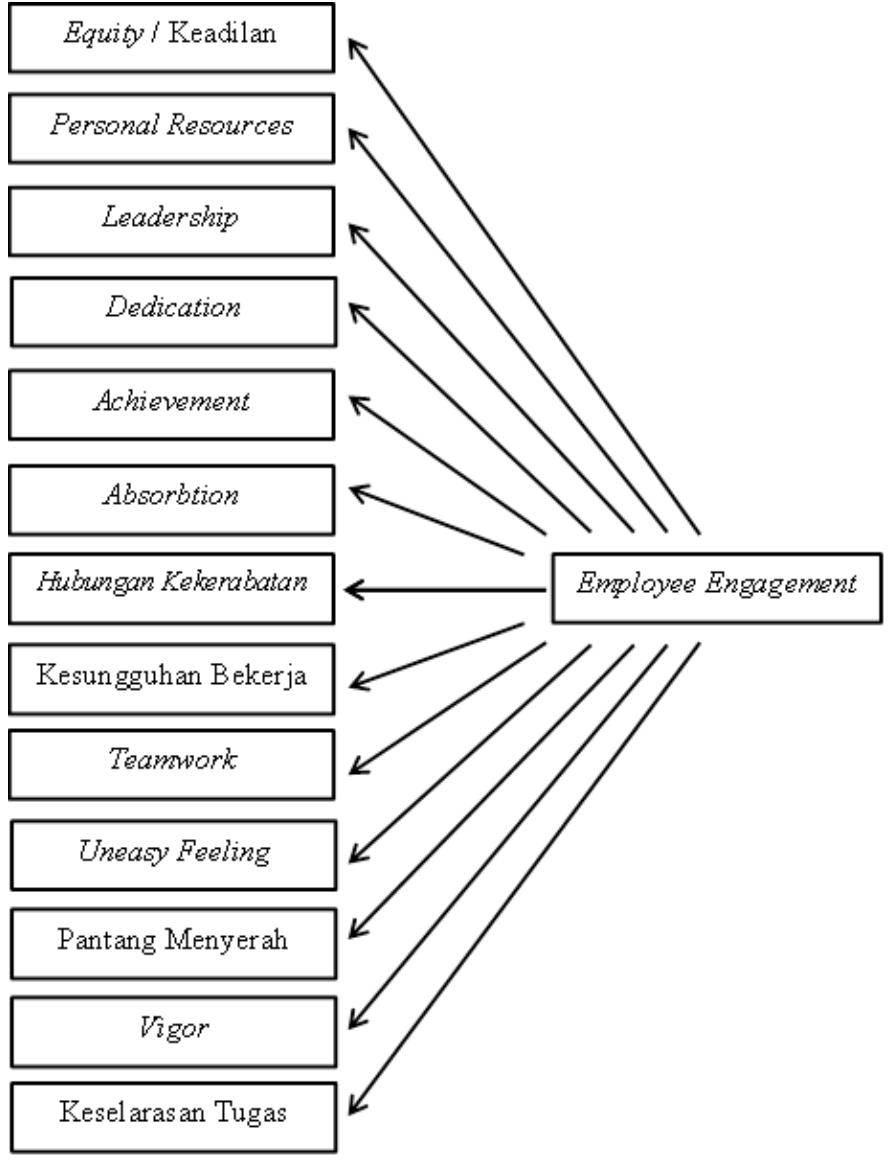

The model that has been proposed as reference model in this research is [22] model and Sirota \& Louis (2005) model which then analyzed to form a new model which is more appropriate to describe factors affecting employee engagement of Y Padma Hotel Bandung.

With the formation of 13 factors, it can be determining the level of employee engagement then it has answered what the research's question. Of these thirteen factors can also be used as a reference to improve employee engagement. What has been done by Padma Hotel Bandung so far through the provision of remuneration as a form of extrinsic motivation was already appropriate. However, remuneration is not the only factor determining the level of employee engagement but there are also other factors that influence management strategy in Padma Hotel Bandung. need to consider the thirteen factors (as well as item indicators). Getting justice from management becomes the first factor determinant of the high level of employee engagement of Y genes. Justice in question is fair both psychologically and economically.

Equity in the psychological aspect in the form of the creation of comfortable working conditions and obtain adequate facilities and tailored to the position of employees. Equity in the economic aspect is fair in terms of work load in accordance with the level of remuneration received.

Knowing factors influencing employee's employee engagement level make Padma Hotel Bandung has a more directional pattern in improving programs that increase employee engagement. This suggests that there needs to be a policy approach from management to increase emotional attachment between employees and organizations.

\section{CONCLUSIONS}

The level of employee engagement $\mathrm{Y}$ gene in Padma Hotel Bandung included in high category that is equal to $76.756 \%$

Factors affecting the level of employee engagement $\mathrm{Y}$ gene at Padma Hotel Bandung are as follows: equity, personal resources, leadership, dedication, achievement, absorbtion, kinship, earnestness work, teamwork, uneasy feeling, unyielding, vigor, and Task alignment

\section{REFERENCES}

[1] Amstrong, Michael dan Taylor, Stephen. (2014). Handbook of Human Resources Management Practice, 14th Edition. New York: Kogan Page Limited.

[2] Anggraini, L., Astuti, Endang Siti, dan Prasetya, Eric. (2016) Faktor-Faktor yang Mempengaruhi Employee Engagement Generasi Y (Studi Pada Karyawan PT Unilever Indonesia Tbk-Surabaya). Jurnal Administrasi Bisnis (JAB), Vol 37, No 2. Hal 183-191.

[3] Corace, C. J. (2007). Engagement Enrolling the Quiet Majority. Organizational Development Journal, Vol 25. Hal 171-175.

[4] Crampton, M., dan Hodge, W. (2009). Generation Y: Unchartered Territory. Journal of Business \& Economics Research, Vol 7, No 14, Hal 1-6.

[5] Endres, Grace M. dan Mancheno-Smoak, Lolita. (2008). The Human Resource Craze: Human Performance Improvement and Employee Engagement. Organization Development Journal, Vol 26, No 1. Hal 69-78.

[6] Erickson, T.J. (2008). Plugged In The Generation Y Guide to Thriving at Work. Boston, MA: Harvard Business Press.

[7] Fitz-Enz, Jac \& Davidson, Barbara. (2011). How to Measure Human Resources Management. Jakarta: Kencana.

[8] Hair, J. F. (2010). Multivariate Data Analysis: A Global Perspective (7th ed). Upper Saddle River, N.J.: Pearson Education.

[9] Hasibuan, Malayu S.P. (2003). Manajemen Sumber Daya Manusia, Edisi Revisi. Jakarta: PT Bumi Aksara. 
[10] Hawkins, Del I., et al. (2007). Consumer Behaviour Building Marketing Strategy. New York: MacGraw Hill.

[11] Horeczy, Andrea., et al. (2012). Leadership Preferences of Generation Y. Hal 1-12. Retrieved from Seanlyons.ca Journal Database.

[12] Kahn, W. A. (1990). Psychological Conditions of Personal Engagement and Disengagement at Work. Academy of Management Journal, Vol 33, Hal 692-724.

[13] Kompaso, Solomon Markos dan Sridevi, M. Sandhya. (2010). Employee Engagement : The Key to Improving Performance. International Journal of Bussiness and Management, Vol 5, No 12. Hal 89-96.

[14] Kourdi, Jeremi. (2009). Business Strategy: A Guide to Taking Your Business Forward. London: Profile Books Ltd.

[15] Kourdi, Jeremy. (2009). 100 Great Business ldeas. Singapore: Marshall Carvendish lnternational.

[16] Macey, William H., et al. (2009). Employee engagement: Tools for Analysis, Practice \& Competitive Advantage. UK: WilleyBlackwell.

[17] Queiri, Abdelbaset, Wan Yusoff, Wan Fadzilah, dan Dwaikat, Nizar. (2015). Explaining Generation-Y Employees' Turnover in Malaysian Context. Asian Social Science Journal, Vol 11, No 10. Hal 126-138.
[18] Robert Half International. (2007). What Millennial Workers Want: How to Attract and Retain Gen Y Employees. Hal 1-17.

[19] Rochaety, Ety; et al. (2007) Metodologi Penelitian Bisnis: Dengan Aplikasi SPSS. Jakarta: Penerbit Mitra Wacana Media.

[20] Saks, Alan M. (2006). Antecedents and Consequences of Employee Engagement. Journal of Managerial Psychology, Vol 21, No 7. Hal 600-619. Retrieved from Emerald Insight Journal Database.

[21] Schaufeli, et.al. (2002). Burnout and Engagement in University Students: A Cross-National Study. Journal of Cross-Cultural Psychology, Vol 33, No 5. Hal 464-481.

[22] Schaufeli, W. B., dan Bakker, A. (2004). UWES: Utrecht Work Engagement Scale. Utrecht University: Occupational Health Psychology Unit.

[23] Schiffman, Leon G., dan Kanuk, Leslie Lazar. (2007). Consumer Behavior, Ninth Edition. New Jersey: Pearson Education International.

[24] Simamora, Bilson. (2005). Analisis Multivariat Pemasaran. Jakarta: PT Gramedia Pustaka Utama. 